$10 / 919197 \% 50$

U.S. Department of Energv CERCLA Information Brief
DOE/EH - 4 - $13 / 9707(6 / 77)$

Office of Environmental Policy and Assistance DOE/EH-413/9707 (June 1997)

\title{
Determinations of TSD Facility Acceptability Under the CERCLA Off-Site Rule
}

BACKGROUND:

September 22, 1993, the U.S. Environmental Protection Agency (EPA) published the "Off-Site Rule" [58 FR A9200 (codifying 40 CFR 300.440)], to imptement section 121(d)(3) of the Comprehensive Environimental Response Compensation and Liability Act (CERCLA). CERCLA \$121(d)(3) requires that wastes generated as a result of remediation activities taken under CERCLA authority and transferred offsite be managed only af facilities that comply with the Resource Conservation and Recovery Act (RCRA), as amended by the Hazardous and Solid Waste Amendments (HSWA) of 1984, or other applicabte Federal laws, and appilicable state requirements. Among other things, the Off-Site Rule establishes the types of wastes to which it applies and provides a mechanism for ensuring that hazardous waste management facilities that receive CERCLA remediation wastes meet the compliance requirements of CERCLA section 121(d)(3).

In 1994, the DOE's Office of Environmental Policy and Assistance (OEPA), RCRACERCLA Division (EH. 413) [formerly the Office of Environmental Guidance, RCRACERCLA Division (EH-231)] published a CERCLA Information Brief titted "The Off-Site Rule" (EH-231-020/0394, March 1994) which describes the content of the Off-Site Rufe and clarifies some of its implications for DOE remedial actions under CERCLA. Additionally, EH-413 published the Gujde on Selacting Compliant Off Sita Hazardous Waste Treatment, storage and DIsposal Faciliffes (DOE/EH-0427. September 1994) which provides a "regulatory roadmap" for accomplishing off-site fransfers of environmentat restoration and process hazardous waste at DOE facilities in a manner compliant with the Off-Site Rule and other relevant Federal regulations. Those guidance documents concentrate primarily on DOE's perspective as a hazardous waste generator. The purpose of this Information Brief is to address the implications of the Off-Site Rule for DOE-owned hazardous waste treatment, storage or disposal facilities that accept CERCLA remediation wastes from off-site locations.

STATUTES: - Comprehensive Environmental Response Compensation and Liability Act (CERCLA), as amended by the Superfund Amendments and Reauthorization Act (SARA) of 1986, \$121(d)(3) [42 U.S.C. $9621(d)]$.

- Resource Conservation and Recovery Act (RCRA), as amended by the Hazardous and Solid Waste Amendments (HSWA) of 1984, Subtitle C [42 U.S.C. 6921 - 6939e].

- Federal Water Pollution Control Act, as amended by the Clean Water Acf (CWA) of 1977, \$311 [33 U.S.C.: 1321].

REGULATIONS:

- 10 CFR Part 300, "National Oit and Hazardous Substances Pollution Contingency Plan."

- 33 CFR Part 153, "Control of Pollution by Oil and Hazardous Substances, Discharge Removal."

REFERENCES: 1. The Off-Site Rule, DOE Office of Environmental Guidance Inow the Office of Environmental Policy and Assistance (EH-413)], CERCLA Information Brief EH-231-02010394 (March 1994).

2. Gulde to Selecting Compltant Off-Site Hazardous Waste Treatment, Storage and DIsposal Facillties, DOE Office of Environmental Guidance [now the Office of Environmental Policy and Assistance (EH-413)l: Environmental Guidance DOE/EH-0427 (September 1994).

3. "Clarification of NPL Listing Policy," Memorandum from EPA Office of Emergency and Remedial Response, U.S. Environmental Protection Agency, August 3, 1995.

4. "Clarification of National Priorities List (NPL) Listing Policy," Memorandum from DOE Office of Environmental Policy and Assistance, RCRAJCERCLA Division (EH 113), January 29, 1997.

5. Delettons of Federal Facilttes from the Foderal Agency Hazardous Waste Compliance Docket and the Nattonal Priortftes List, DOE Office of Environmental Policy and Assistance (EH-413), CERCLA Information Brief EH-413-07410597 (May 1997).

6. "Revised Procedures for Planning and Implementing Off-Site Response Actions," Memorandum from EPA Assistant Administrator, November 13, 1987.

\section{WHAT IS AN "ACCEPTABLITY DETERMINATION" UNDER THE OFF-SITE RULE?}

An "acceptability determination" is the process by which EPA evaluates an off-site facility's acceptability to receive CERCLA waste.
Under the Off-Site Rule, EPA must determine the acceptability of each off-site waste management facility selected to treat, store, or dispose of CERCLA waste before the facility receives CERCLA waste for the first time [40 CFR 300.440(a)(4)]. The evaluation criteria are presented in the response to question 4 , below.

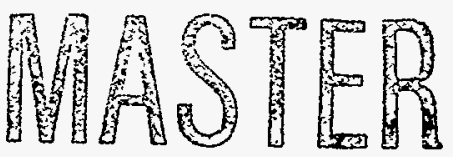




\section{WHICH TSD UNITS MUST UNDERGO ACCEPTABUITY DETERMINATIONS?}

A waste treatment, storage, or disposal (TSD) unit would be required to undergo an acceptability determination if:

- The unit does or will receive "CERCLA waste" or cleanup waste resulting from a removal action taken under section 311(c) of the CWA; and

- The unit is or will be located "off-site."

This means that evaluating whether a TSD unit must undergo an acceptability determination requires an understanding of the definitions of the terms "CERCLA waste," CWA $\$ 311$ (c) removal action cleanup waste, and "off-site."

\section{- DEFINITION OF CWA \$311(c) REMOVAI ACTION CLEANUP WASTE}

A detailed discussion of the nature of cleanup waste from a CWA section 311 (c) removal action is beyond the scope of this Information Brief. Generally however, such waste is generated during cleanup of a discharge of oil or a hazardous substance into navigable waters of the United States. If DOE or DOE contractor personnel suspect that a TSD unit for which they have responsibility may receive CWA section 311 (c) cleanup waste, they should consult 33 CFR Part 153, "Control of Pollution by Oil and Hazardous Substances, Discharge Removal," for additional information on the definition of such waste.

\section{- DEFINITION OF CERCLA WASTE}

CERCLA waste is defined for purposes of the Off-Site Rule by 40 CFR 300.440 (a)(1), which is located within the National Oil and Hazardous Substances Pollution Contingency Plan (NCP) (40 CFR Part 300).

Pursuant to the NCP, CERCLA waste is waste that:

- Results from a CERCLA-authorized or CERCLAfunded response action; and

- Contains at least one substance defined by CERCLA section 101(14) as a hazardous substance; or

- Contains at least one substance defined by CERCLA section 101(33) as a pollutant or contaminant. include:

Categories of waste that could be CERCLA waste

- Laboratory sample waste,

- Treatability study waste,

- Emergency response waste,

- Investigation-derived waste, and

- CERCLA response action waste.

Reference 2 describes the types of waste included in each category. DOE TSD facilities that receive waste in the first three categories may not be required to undergo an acceptability determination, even though such waste is CERCLA waste because:

- Laboratory sample waste and treatability study waste are exempt from Off-Site Rule requirements [40 CFR $300.440(\mathrm{a})(5)] ;$ and

- CERCLA On-Scene Coordinators ${ }^{1}$ are given discretion to transfer emergency response waste to an off-site location without first ensuring compliance with the Off-Site Rule [40 CFR 300.440(a)(2)].

DOE TSD facilities that receive CERCLA investigation-derived waste or CERCLA response action waste would be required to undergo acceptability determinations.

\section{DEFINITION OF OFF-SITE}

Neither CERCLA nor the NCP defines the term "off-site." Therefore, for this Information Brief a definition of "off-site" is derived from the NCP's definition of "on-site."

In 40 CFR 300.400(e)(1), the NCP defines "on-site" as an area that includes:

- The areal extent of contamination; and

- All suitable areas in very close proximity to the contamination that are necessary for implementation of the response action.

Prior to August 1995, the "on-site" area for a CERCLA National Priorities List (NPL) site located at a Federal facility was usually delineated by the property boundaries of the Federal facility on which it was located (ref. 5). In August 1995, EPA issued a policy memorandum to clarify "the perception that [CERCLA NPL sites located at large] facilities are listed on a fenceline-to-fenceline basis" (ref. 3). According to that memorandum and subsequent $\mathrm{DOE}$ guidance (see ref. 4), an NPL-listed CERCLA site is not defined by the geographic boundaries of the facility where it is located. Rather, only areas of contamination and certain areas in close proximity to such areas of contamination comprise the CERCLA site. This clarification confirms that:

- If a DOE TSD unit is not located within the area of contamination at a CERCLA site, or in close proximity, it is an "off-site" unit with respect to any CERCLA waste it receives, even if such waste is generated at a CERCLA site located within the boundaries of the same DOE facility; and

- If a DOE TSD unit is located within the area of contamination at a CERCLA site, or in close proximity, it is an on-site unit only for the CERCLA waste generated within the CERCLA site where it is located.

1 The On-Scene Coordinator at a CERCLA hazardous release response site is the official designated by the lead agency to coordinate and direct removal actions under the NCP. At a DOE CERCLA site, where DOE is the lead agency, this official would be designated by DOE. At any CERCLA site where EPA is the lead agency, this official would be designated by EPA. 


\section{DISCLAIMER}

This report was prepared as an account of work sponsored by an agency of the United States Government. Neither the United States Government nor any agency thereof, nor any of their employees. make any warranty, express or implied, or assumes any legal liability or responsibility for the accuracy, completeness. or usefuiness of any information, apparatus, product, or process disclosed, or represents that its use would not infringe privately owned rights. Reference herein to any specific commercial product, process, or service by trade name. trademark, manufacturer, or otherwise does not necessarily constitute or imply its endorsement, recommendation, or favoring by the United States Government or any agency thereof. The views and opinions of authors expressed herein do not necessarily state or reflect those of the United States Government or any agency thereof. 


\section{DISCLAIMER}

Portions of this document may be illegible in electronic image products. Images are produced from the best available original docament. 


\section{HOW AND WHEN ARE ACCEPTABMITY DETERMINATIONS INITIATED, AND WHO CONDUCTS THEM?}

The Off-Site Rule mandates that EPA complete all acceptability determinations. Hence, EPA Regional offices usually initiate the process. However, as the response to question 4 (below) explains, EPA bases each acceptability determination on the candidate TSD facility's compliance with both state and Federal laws, and on control of hazardous releases at the facility. In reality, States are often more familiar than EPA with such aspects of TSD facility operation. For this reason, EPA typically collaborates closely with the State in which the candidate TSD facility is located.

If a TSD facility for which no prior acceptability determination has been completed is used by DOE and is expected to receive off-site CERCLA wastes, the TSD facility owner/operator should notify both the EPA Regional office and the responsible agency in the State in which the facility is located as soon as practicable. The notice should request that an acceptability determination be initiated. The Off-Site Rule does not require this notice. Nevertheless, as a practical matter, the regulatory agencies need a mechanism for identifying TSD facilities for which acceptability determinations must be made.

After EPA initiates an acceptability determination, either the EPA Regional office or the State will inspect the TSD facility for relevant releases and relevant violations of state and Federal requirements [40 CFR 300.440(c)(1) - (3)]. An inspection may not be necessary if existing information is adequate to identify current releases and violations [e.g., a RCRA Facility Assessment (RFA) or other inspection has recently been completed] (ref. 6).

\section{WHAT ARE THE CRITERIA FOR ACCEPTABLITY UNDER THE OFF-SITE RULE?}

The provisions of 40 CFR $300.440(\mathrm{~b})$ establish the following acceptability criteria for off-site TSD facilities:

- There must be no relevant violations at or affecting the unit or units receiving CERCLA waste (i.e., the "receiving units"); and

- Relevant releases must be addressed prior to the facility's initial receipt of CERCLA waste

\section{- RELEVANT VIOLATIONS}

According to $40 \mathrm{CFR} 300.440$ (b)(1), relevant violations are the following:

- Criminal violations which result in indictment;

- Significant deviations from regulation;

- Significant deviations from compliance order provisions; and
- Significant deviations from permit conditions designed to:

- Ensure that CERCLA waste is destined for and delivered to authorized facilities;

- Prevent hazardous releases to the environment;

- Ensure early detection of such releases; or

- Compel corrective action for releases.

Other violations that $40 \mathrm{CFR} 300.440(\mathrm{~b})(1)$ indicates EPA may consider relevant are violations of:

- $\quad$ Applicable subsections of RCRA sections 3004 (Standards Applicable to Owners and Operators of Hazardous Waste Treatment, Storage, and Disposal Facilities) and 3005 (Permits for Treatment, Storage or Disposal of Hazardous Waste);

- Applicable sections of other Federal laws (such as the Toxic Substances Control Act and subtitle D of RCRA); and

- Applicable sections of state environmental laws.

Finally, if the unit receiving off-site CERCLA waste is a land disposal unit located at a RCRA subtitle $C$ facility, and the CERCLA waste is RCRA hazardous waste, the receiving unit must be in compliance with the minimum technological requirements of RCRA section 3004(o), unless the unit has been granted a waiver under 40 CFR 264.301 (Landfill Design and Operating Requirements) [40 CFR $300.440(\mathrm{~b})(\mathrm{l})(\mathrm{ii})(\mathrm{C})]$.

\section{口 RELEVANT RELEASES}

\section{Definition of Relevant Release}

Unless specifically excluded, any hazardous release as defined by the NCP, or the threat of such a release, is considered to be a relevant release under the Off-Site Rule when it occurs from a waste management unit located at a TSD facility intending to receive off-site CERCLA waste.

The NCP defines a release as any spilling, leaking, pumping, pouring, emitting, emptying, discharging, injecting, escaping, leaching, dumping, or disposing into the environment (including the abandonment or discarding of barrels, containers, and other closed receptacles containing any hazardous substance or pollutant or contaminant (40 CFR 300.5).

Events specifically excluded by 40 CFR 300.5 from the definition of release are the following:

- The normal application of fertilizer;

- Any release which results in exposure to persons solely within a workplace, with respect to a claim which such persons may assert against their employer;

- Emissions from the engine exhaust of a motor vehicle, rolling stock, aircraft, vessel, or pipeline pumping station engine;

- A release of source, byproduct, or special nuclear material from a nuclear incident, as those terms are defined in the Atomic Energy Act of 1954, if such 
release is subject to requirements with respect to financial protection established by the Nuclear Regulatory Commission under section 170 of such Act; and

- For the purposes of section 104 of CERCLA or any other response action, any release of source, byproduct, or special nuclear material from any processing site designated under section $102(a)(1)$ or 302(a) of the Uranium Mill Tailings Radiation Control Act of 1978 (42 U.S.C. 7901 et seq.).

Additionally, the events listed below are excluded from the definition of release for purposes of the Off-Site Rule by 40 CFR 300.440 (b)(2)(i):

- De minimis releases;

- Releases permitted under Federal programs or under Federal programs delegated to the States, unless such releases pose a threat to human health and the environment; and

- Releases to the air that do not exceed applicable standards promulgated pursuant to RCRA section 3004(n) (Air Emissions at Hazardous Waste Treatment, Storage, and Disposal Facilities), or if such standards do not apply, releases to the air that do not present a threat to human health or the environment.

\section{Addressing Relevant Releases}

In order for EPA to deem a RCRA subtitle C TSD facility acceptable under the Off-Site Rule, $40 \mathrm{CFR}$ 300.440 (b)(2)(ii) requires that the facility be addressing relevant releases in the following ways:

- No releases can be occurring from the unit or units that are or will be receiving CERCLA waste (i.e., the receiving units); and

- A RCRA subtitle C enforceable agreement (e.g., an order, permit or decree) for corrective action must control any releases from:

- Non-receiving units at a land disposal facility, whether or not the receiving unit is a land disposal unit; and

- Non-receiving units at a treatment, storage, or permit-by-rule facility, if such releases pose a significant threat to human health or the environment.

If the facility is subject to state or Federal authorities other than RCRA subtitle $\mathrm{C}$, a determination that the facility is acceptable can be made only if relevant releases are being controlled by an enforceable agreement (e.g., an order, permit or decree) for corrective action issued under the applicable Federal or state authority.

EPA deems an enforceable agreement for corrective action to control a release at a RCRA subtitle C TSD facility if upon issuance, the agreement initiates and requires completion of one or more of the following:

- A RCRA Facility Investigation;
- A RCRA Corrective Measures Study; and/or

- Implementation of RCRA Corrective Measures. [40 CFR 300.440(b)(2)(iii) and 40 CFR 300.440(f)(3)(iv)]

EPA deems an enforceable agreement for corrective action to control a release at a facility subject to state or Federal authorities other than RCRA subtitle $\mathrm{C}$ if, upon issuance, the agreement initiates and requires, pursuant to the applicable state or Federal laws, one or more of the following:

- A facility investigation;

- A corrective action study; and/or

- Implementation of corrective measures.

[40 CFR 300.440(b)(2)(iii) and (40 CFR 300.440(f)(3)(v)].

At both RCRA subtitle $\mathrm{C}$ facilities and TSD facilities not subject to RCRA subtitle $C$, a release remains controlled as long as the facility continues to comply with the applicable enforceable agreement. If additional corrective measures become necessary that were not required by the original agreement, the release will remain controlled as long as the facility enters into and complies with a subsequent enforceable agreement covering the new corrective measures [40 CFR 300.440(f)(3)(iv) and (v)].

At both RCRA subtitle $\mathrm{C}$ facilities and TSD facilities not subject to RCRA subtitle $C$, if an enforceable agreement for corrective action is issued, but the facility challenges the agreement's corrective action provisions, a relevant release at the facility will not be considered controlled until the challenge is resolved, unless the facility:

- Satisfies the EPA Regional Office that adequate interim corrective measures will continue; or

- Demonstrates to the EPA Regional Office that corrective action during the short-term, interim period of the challenge is not needed [ $40 \mathrm{CFR}$ 300.440(b)(2)(iii) and 40 CFR 300.440(e)].

\section{WHAT HAPPENS IF EPA DETERMINES THAT A DOE TSD FACILTY IS NOT ACCEPTABLE TO RECEIVE OFF-SITE CERCLA WASTE?}

If the responsible EPA Regional Office makes an initial determination that a DOE TSD facility does not meet the acceptability criteria for receiving off-site CERCLA waste, the Regional Office will provide notice of the unacceptability determination by certified mail to both the DOE TSD facility and the State in which the facility is located [40 CFR 300.440 (d)(1). This notice of unacceptability must:

- State that the facility has been found to not meet the requirements of 40 CFR 300.440 ;

- Indicate the sources of information used to make the finding (e.g., RFA, inspection, or other data sources);

- Cite the specific acts, omissions, or conditions that form the basis of the findings; and

- Inform DOE of the procedural recourse available [40 CFR 300.440(d)(2)]. 
From the date of issuance of the notice of unacceptability, the facility may continue to receive CERCLA waste for 60 calendar days, unless the EPA Region decides otherwise [40 CFR 300.440(d)(3)].

Figure 1 illustrates the administrative process that EPA must follow after issuing a notification of unacceptability. The figure provides a citation to the applicable section of the Off-Site Rule (40 CFR 300.440) for each step in the process. If a DOE facility receives a notice of unacceptability, responsible TSD facility owner/operator should consult the cited regulations for process details.

\section{CAN A FACILITY DETERMINED TO BE UNACCEPTABLE BE RE-EVALUATED?}

Yes. The Off-Site Rule provides for reconsideration of a waste TSD facility's acceptability provided that the responsible EPA Regional Office finds that the facility fulfills the criteria discussed in the response to question 4, above. Upon making such a finding, the EPA Regional Office must give written notice to the facility and the State in which the facility is located. [40 CFR $300.440(f)(5)$ ]

Additionally, if a DOE TSD facility remains unacceptable after having received a notification of unacceptability and conferring with EPA and the State as depicted on Figure 1, the facility can regain acceptability by meeting the applicable conditions listed below.

\section{JUDGMENT ON THE MERITS}

- The facility challenges EPA's finding of relevant violations or uncontrolled releases that was the basis for the original notice of unacceptability, and the facility wins the challenge because the finding is determined to have been factually incorrect [40 CFR 300.440(f)(1)].

\section{R RECTIFY RELEVANT VIOLATIONS}

- The facility demonstrates to the EPA Region that it has corrected all relevant violations cited in the original notice of unacceptability and has achieved physical compliance [40 CFR 300.440(f)(2)].

\section{A ADDRESS RELEVANT RELEASES}

- If the facility is a RCRA subtitle C facility, the facility demonstrates to the EPA Region that relevant releases are being addressed in the following ways, as appropriate:

- All releases from receiving units have been eliminated and prior contamination from such releases is being controlled by a corrective action program approved under subtitle $\mathrm{C}$ of RCRA (i.e., a permit, order or decree) [40 CFR 300.440(f)(3)(i)];
- All releases from non-receiving units at land disposal facilities are being controlled by a corrective action program approved under subtitle C of RCRA [40 CFR 300.440(f)(3)(ii)];

- All releases from non-receiving units at treatment and storage facilities either pose no significant threat to human health or the environment, or are being controlled by a corrective action program approved under subtitle C of RCRA [40 CFR 300.440(f)(3)(iii)].

- If the facility is regulated under Federal or state laws other than RCRA subtitle $C$, one of the following has occurred:

- The EPA Regional Office has judged all releases to pose no threat to human health or the environment; or

- The facility has entered into an enforceable agreement pursuant to the applicable laws to conduct corrective action activities to control releases. [40 CFR 300.440(f)(3)(v)]

Prior to issuing a determination of acceptability upon reevaluation, the EPA Region must notify the State in which the facility is located of its intent, and provide an opportunity for the State to discuss the facility's acceptability status with EPA. [40 CFR 300.440(f)(4)]

Quetoms of policy or questions requiring policy: decistaris will not be deall with th EH 4 I3 Infarmation Brtefs unless that policy has atready been sestabits hed through appropitate doetimentation. Pleatse refer any questions concerning the material covered in thits Information Brtef to Beverty Whitehedd, RCRAICERCLA Dinision, $14-4.13$ by callitis (202) $586-6073$ or communicafins electrontedtly,

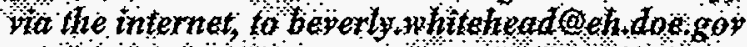
से की

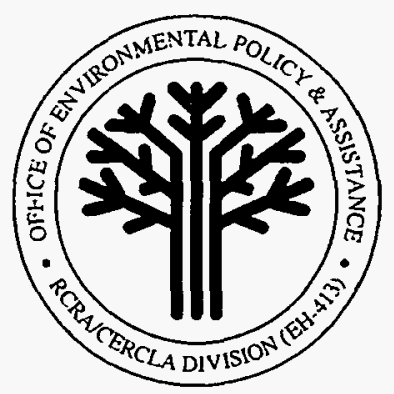


FIGURE 1: Processing a Determination of Unacceptability [40 CFR 300.440(d)]

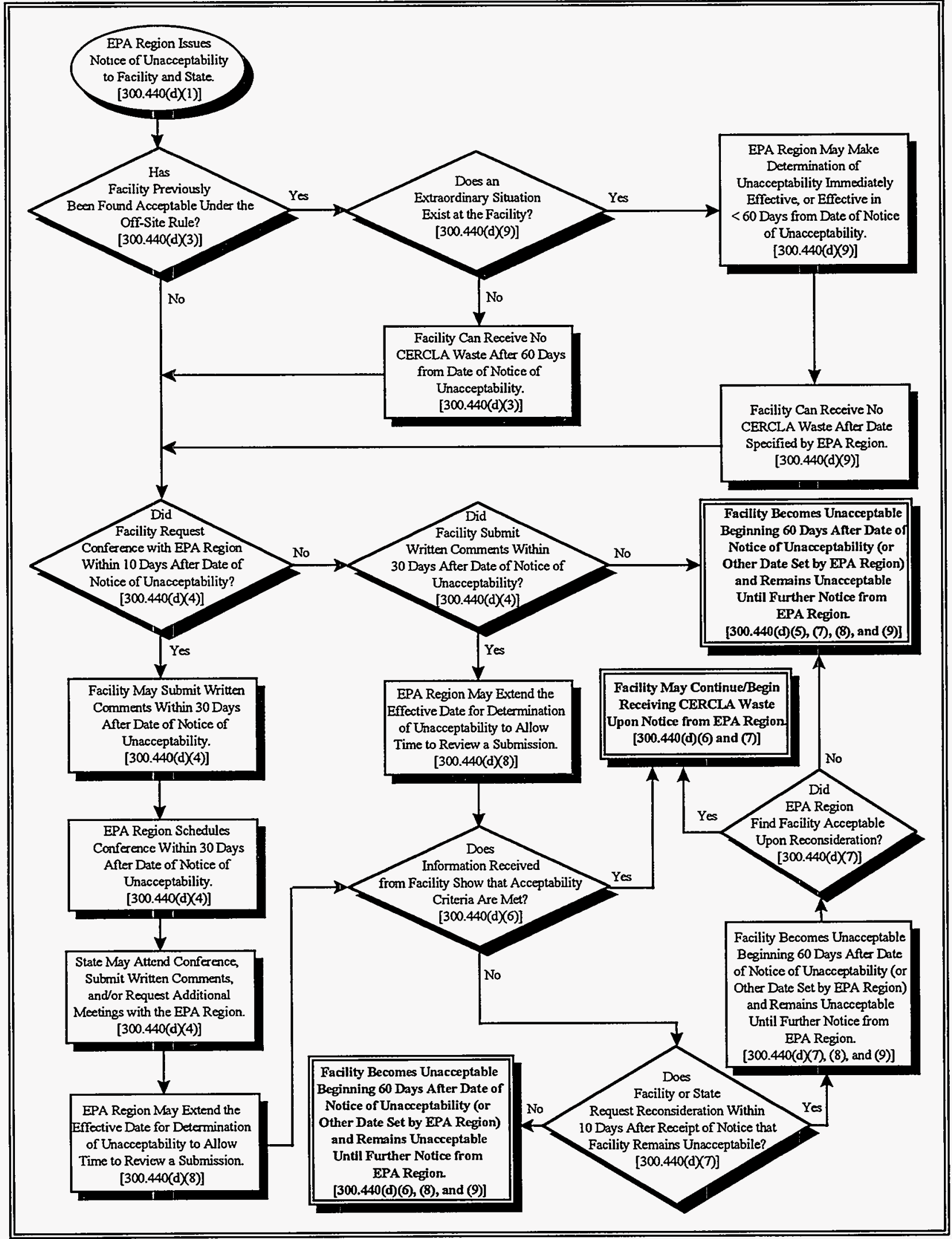

